\title{
Extraction of Oil from Egyptian Oil Shale
}

\author{
Ramadan Abu AI-Alla and Ehssan Nassef*
}

Petrochemical Department, Faculty of Engineering, Pharos University, Alexandria, Egypt

\begin{abstract}
Oil shales are defined as fine grained sedimentary rocks containing abundant mainly sapropelic organic matter which produce oil on distillation. The present study highlights the characterization of Egyptian origin oil shale using various analytical techniques such as Elemental analysis, Infrared spectroscopy (IR), and the Morphology Study of oil shale (SEM). The study is focused on the characterization of shale oil samples obtained by solvent extraction method from oil shales. The paper studied the effect of amount and type of solvent, time of extraction, the temperature of retorting on the percentage yield of oil produced. The study is also focused on the analysis of shale oil samples by gas chromatography (G.C) and thermal analysis (T.G.A) which revealed that the oil has a high value of hydrocarbons. From Experimental studies it is found that the percentage yield of oil increased as the volume of solvent increased the best result is obtained by using methanol as a solvent. The yield also increased by increasing time of extraction and stirring rate.
\end{abstract}

Keywords: Oil shale; Solvent extraction; Shale oil; Characterization; Elemental analysis; Yield

\section{Introduction}

Oil shale is commonly defined as a fine-grained sedimentary rock containing organic matter that yields substantial amounts of oil and combustible gas upon destructive distillation. Most of the organic matter is insoluble in ordinary organic solvents; therefore, it must be decomposed by heating to release such materials. Underlying most definitions of oil shale is its potential for the economic recovery of energy, including shale oil and combustible gas, as well as a number of byproducts [1]. In terms of mineral and elemental content, oil shale differs from coal in several distinct ways. Oil shales typically contain much larger amounts of inert mineral matter (60-90 percent) than coals, which have been defined as containing less than 40 percent mineral matter. The organic matter of oil shale, which is the source of liquid and gaseous hydrocarbons, typically has a higher hydrogen and lower oxygen content than that of lignite and bituminous coal $[2,3]$. In general, the precursors of the organic matter in oil shale and coal also differ, much of the organic matter in oil shale is of algal origin, but may also include remains of vascular land plants that more commonly compose much of the organic matter in coal. The origin of some of the organic matter in oil shale is obscure because of the lack of recognizable biologic structures that would help to identify the precursor organisms. Such materials may be of bacterial origin or the product of bacterial degradation of algae or other organic matter [4,5]. The mineral component of some oil shales is composed of carbonates including calcite, dolomite, and siderite, with lesser amounts of alumino silicates. For other oil shales, the reverse is true-silicates including quartz, feldspar, and clay minerals are dominant and carbonates are a minor component. Many oil-shale deposits contain small, but ubiquitous, amounts of sulfides including pyrite and marcasite, indicating that the sediments probably accumulated in dysaerobic to anoxic waters that prevented the destruction of the organic matter by burrowing organisms and oxidation $[5,6]$. Oil shale differs from coal whereby the organic matter in coal has a lower atomic $\mathrm{H}$ : $\mathrm{C}$ ratio [6,7]. The heating value of the oil shale may be determined using a calorimeter. The heating value is useful for determining the quality of an oil shale that is burned directly in a power plant to produce electricity. The oil shale industry as represented by the six countries in Figure 1 maintained a combined yearly production of oil shale in excess of 30 million tons from 1963 to 1992. From the peak year of 1981, yearly production of oil shale steadily declined to a low of about 15 million tons in 1999. Most of this decline is due to the gradual downsizing of the Estonian oil shale industry. This decline was not due to diminishing supplies of oil shale but to the fact that oil shale could not compete economically with petroleum as a fossil energy resource. On the contrary, the potential oil shale resources of the world have barely been touched [3]. Eastern Desert of Egypt (Figure 2) is most notable for the presence of the phosphorites of Gebel Duwi Range discovered over 60 years ago. The shales of the Duwi Formation are interbedded with the phosphates of the overlying Dakhla Formation and are generally black to grey and rich enough in organic matter to warrant their description as black shales. The Duwi Formation of Campanian-Maastrichtian age $[8,9]$. Organic association in the shale includes the organic components $\mathrm{C}$, $\mathrm{H}, \mathrm{N}$ and $\mathrm{S}$ which seem to be responsible for accumulation of unusual amounts of some trace elements, especially V. The objective of the

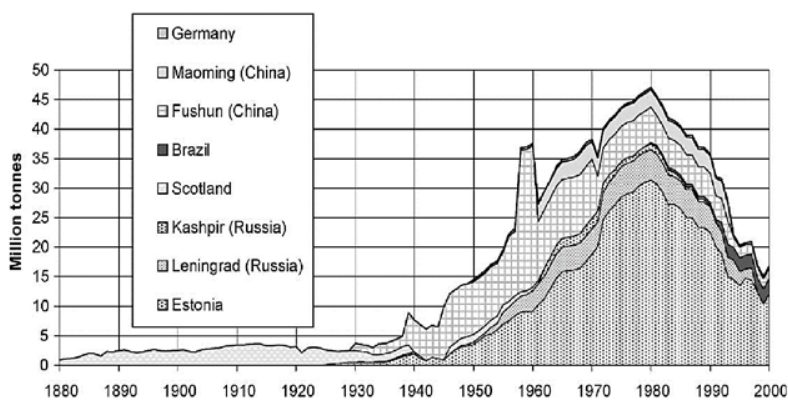

Figure 1: Oil shale, mined from deposits in Brazil, China, Estonia, Germany, Russia and Scotland, 1880-2000.

*Corresponding author: Dr. Ehssan Nassef, Engineering Petrochemical Department, Faculty of Engineering, Pharos University, Alexandria, Egypt, Tel: 01111509333; E-mail: ehssan.nassef@pua.edu.eg

Received December 19, 2014; Accepted January 24, 2015; Published January 31, 2015

Citation: Al-Alla RA, Nassef E (2015) Extraction of Oil from Egyptian Oil Shale. J Pet Environ Biotechnol 6: 205. doi:10.4172/2157-7463.1000205

Copyright: @ 2015 Al-Alla RA, et al. This is an open-access article distributed under the terms of the Creative Commons Attribution License, which permits unrestricted use, distribution, and reproduction in any medium, provided the original author and source are credited. 


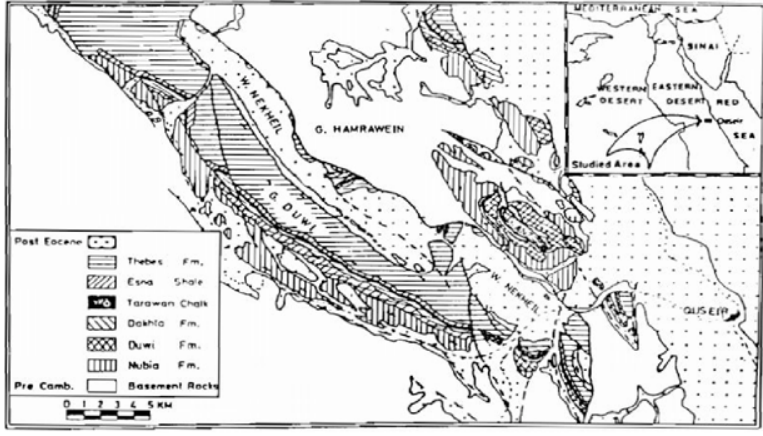

Figure 2: Geologic map of Quseir area and sketch map of Egypt.

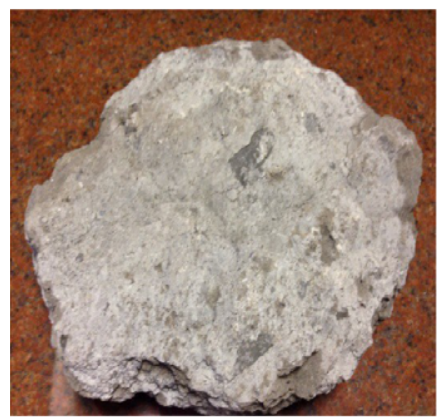

Figure 3: Oil Shale Rock.

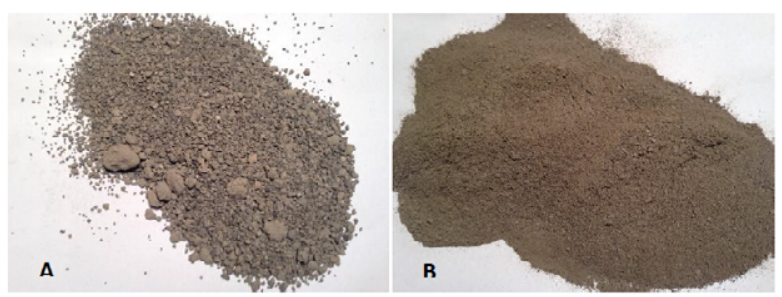

Figure 4: $A$ ) Semi-Crushed Oil Shale; $B$ ) Fully-Crushed Oil Shale.

work of this paper is divided into two parts: part one is concerned with investigations connected with study of composition and structure of oil shale from Al-Quseir area in Egypt which is the most perspective due to its high organic content while the other part is the characterization of shale oil obtained by solvent extraction using different organic solvent. Presented work is also focused on obtaining high percentage yield of oil from oil shale by studying variables like amount and type of solvent, time of reaction, the temperature of retorting.

\section{Materials and Methods}

Oil shale samples were obtained from Al-Quseir area, Egypt. All samples were dark in color. The oil shale samples used as shown in Figure 3 were crushed and sieved to a particle size range around 1-1.5 $\mathrm{mm}$ as shown in Figure 4. The elemental analysis of oil shale was performed at National Research Institute in Cairo, Egypt the data is given in Table 1.

\section{Experimental setup}

The experimental set up used in the present work is schematically

\begin{tabular}{c|c|c|c|c|}
\hline Oil Shale & $\mathbf{C}$ & $\mathbf{N}$ & $\mathbf{S}$ & $\mathbf{H}$ \\
\cline { 2 - 5 } Sample & $4.69 \%$ & $0.06 \%$ & $0.20 \%$ & $1.50 \%$ \\
\hline
\end{tabular}

Table 1: The elemental analysis data of the studied oil shale sample.

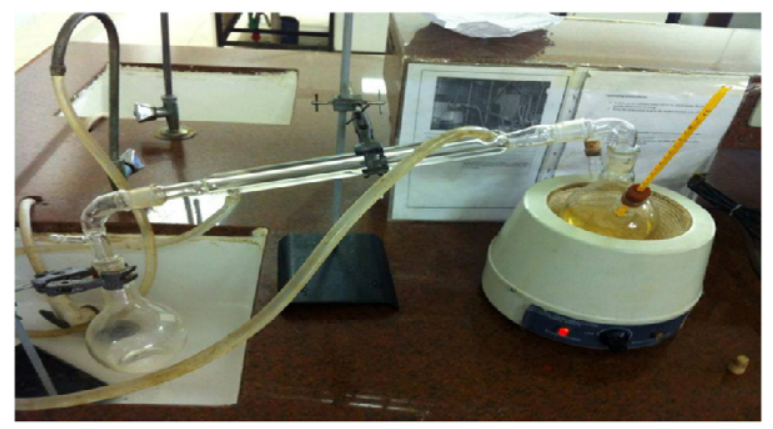

Figure 5: Distillation Unit.

shown in Figure 5. The reaction vessel consists of a conical provided with a mechanical stirrer for mixing the reaction mixture, a hot plate adjusted at temperature reaction. A distillation unit was used to evaporate the solvent. For determining of oil produced weight a digital balance was used.

Procedure of retorting: $100 \mathrm{gm}$ of oil shale were put inside round metal dish (Dimension: $3 \times 10 \mathrm{~cm}$ ) then the metal dish was heated inside the oven at $200^{\circ} \mathrm{C}$ for 10 minutes (without cover) then put the cover of the dish and re-enter the oven and heat at $300^{\circ} \mathrm{C}$ for 120 minutes then the oven was turned off. Leave sample to cool down then weigh the sample.

Procedure of solvent extraction: $100 \mathrm{gm}$ of the crushed sample were stirred by magnetic stirrer in the flask as shown in Figure 5. A known volume of organic solvent was added and the stirring rate was adjusted at the required speed and the mixture was heated on the hot plate at the desired reaction temperature. After a known period the reaction mixture was filtered to separate the extracted oil with solvent then in the distillation unit the solvent can be recovered again.

\section{Results and Discussion}

\section{Analysis (Characterization) of oil shale}

Oil shale elemental analysis: The elemental analysis of oil shale sample was performed at Egyptian Petroleum Research institute in Cairo. The sample of the shale was analyzed on Vario El Elementar Germany instrument. A known weight of a sample about 3-5 mg was carefully weighed in tin boats and put in the auto sampler of the instrument. The sample was burned in oxygen gas at $1150^{\circ} \mathrm{C}$ in the combustion tube. The product of combustion were then reduced by hot copper at $85^{\circ} \mathrm{C}$ producing $\mathrm{N}_{2}, \mathrm{CO}_{2}, \mathrm{H}_{2} \mathrm{O}$ and $\mathrm{SO}_{2}$ which were selectively adsorbed on columns. After heating of the columns they were determined using thermal conductivity detector with helium as carrier gas. The peak height was related to the gas and the percentage of element in the sample was determined. The elemental analysis data of oil shale sample studied is given in Table 1 .

The elemental analysis shows the percentage of carbon $4.69 \%$, hydrogen $1.5 \%$, nitrogen $0.06 \%$, sulfur $0.2 \%$. By comparing These results with the results of Indian origin oil shale sample which contains Carbon 6.1\%, Nitrogen 0.08\%, Hydrogen $1.2 \%$ and Sulfur 2.3\% [10]. 
The organic carbon content is a good indicator of the quality of organic matter in the oil shale. From the previous data it was observed that the Egyptian Oil shale contains much less percentage of $\mathrm{S}$ content than Indian shale and it gives the Egyptian shale a an advantage over to Indian shale because the presence of $S$ content causes a lot of problems and has bad environmental impact specially in extraction of oil from oil shale which need special treatment to get rid of it and this costs a lot of money in industry. By comparing also the sulfur content of Egypt oil shale with The sulfur content of shale oil from the Jurfed Darawish and the Sultani deposits (Jordanian) is high (8-10\%) [11] it gives an indication that Egypt oil shale is better than Jordanian oil shale in this percentage of $\mathrm{S}$ content another comparison of $\mathrm{S}$ and $\mathrm{N}$ content of china oil shale which contains $0.8 \% \mathrm{~S}$ and $0.57 \% \mathrm{~N}[12,13]$. From Table 1 showing that $\mathrm{H} / \mathrm{C}$ ratio is 0.3198 while the $\mathrm{H} / \mathrm{C}$ ratio in Indian shale equal to 0.196 indicating that the Egyptian origin oil shale is carbon rich in nature and contains a significant amount of aromatics than Indian shale. The main characteristics of the organic matter of oil shale are high hydrogen and a low nitrogen percentage [12].

IR analysis: IR spectra of the oil shale sample is analyzed on PerkinElmer BX-II FT-IR instrument. By explaining the chart of IR spectrum of Egyptian origin oil shale as shown in Figure 6. It is observed that there was stretching peaks which indicate the aliphatic and aromatic bonds in the shale. The analysis of the sample shows the presence of various sharp carbon hydrogen bonds $(\mathrm{C}-\mathrm{H})$ in range $3000-4000 \mathrm{~cm}^{-1}$ (3975.42 $\left.\mathrm{cm}^{-1}, 3796.04 \mathrm{~cm}^{-1}, 3618.58 \mathrm{~cm}^{-1}, 3427.62 \mathrm{~cm}^{-1}\right)$. It was also observed that there is a large peak at $3427.62 \mathrm{~cm}^{-1}$ which indicates the $\mathrm{O}-\mathrm{H}$ bond. Also it was observed that aliphatic hydrocarbon stretching bands are found at $2943.47 \mathrm{~cm}^{-1}$. It was also observed that the peaks at $2519.12 \mathrm{~cm}^{-1}$ and $2324.30 \mathrm{~cm}^{-1}$ represent $(\mathrm{C} \equiv \mathrm{C})$ bonds. A large peaks are observed at $1437.02 \mathrm{~cm}^{-1}$ and $1033.88 \mathrm{~cm}^{-1}$ which indicate $\mathrm{C}-\mathrm{C}$ bond and N-H group respectively. Whereas wave length $779.27 \mathrm{~cm}^{-1}$ indicates aromatic compounds specially benzene monosubstituted and di substituted, wave length $536.23 \mathrm{~cm}^{-1}$ indicates C- X bonds in which may be chloroalkanes, bromo alkanes or iodo alkanes, wave length $459.07 \mathrm{~cm}^{-1}$ indicates clay and mineral in oil shale [14-18].

Morphology Study of Oil Shale (SEM): Scanning Electron Microscopy (SEM) of selected samples of oil shale is shown from Figure 7 (performed in City of scientific research \& Technological applications -SRTA City). The purpose of this study is to show distribution of minerals in oil shale and to understand the microstructure relationships

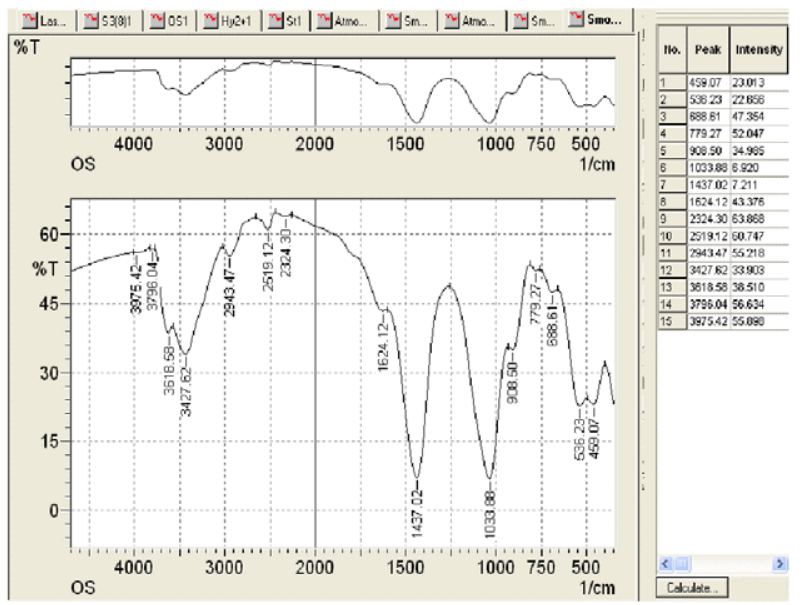

Figure 6: IR Analysis of the oil shale.
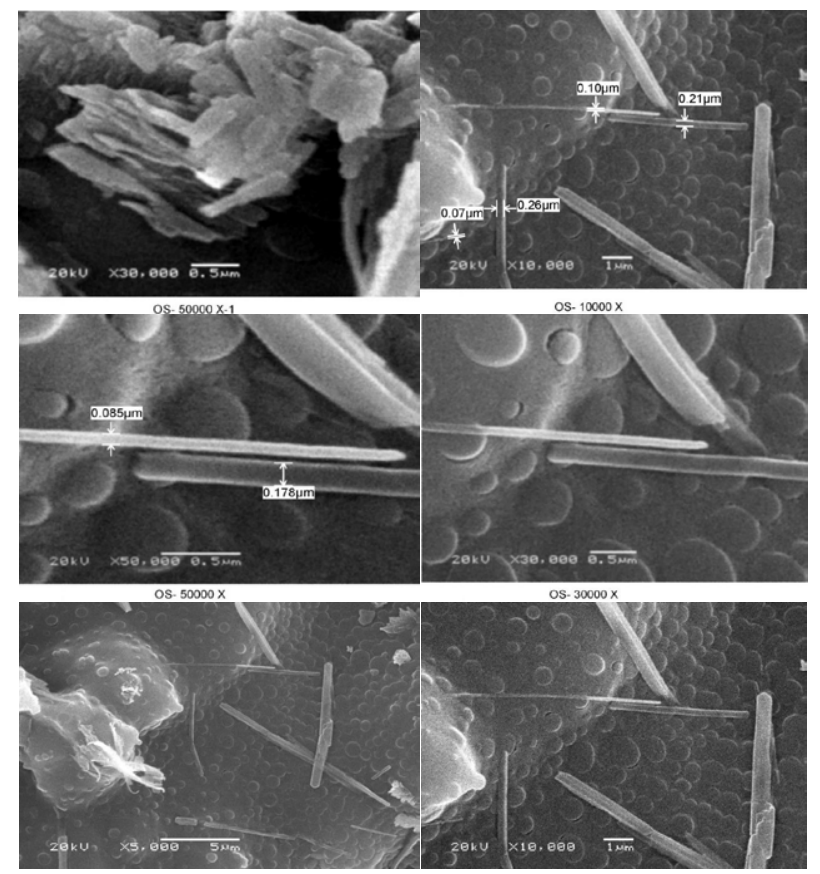

Figure 7: Scanning Electron Microscopy (SEM) for selected samples of oil shale.

\begin{tabular}{|c|c|c|c|c|}
\hline \multirow{2}{*}{ Solvent } & $\mathbf{1 0 0}(\mathbf{m l})$ & $\mathbf{2 5 0}(\mathbf{m l})$ & $\mathbf{5 0 0}(\mathbf{m l})$ & $\mathbf{7 0 0}(\mathbf{m l})$ \\
\cline { 2 - 5 } & Yield/ml & Yield/ml & Yield/ml & Yield/ml \\
\hline MEK & 3.5 & 4 & 4.3 & 4.5 \\
\hline Methanol & 8 & 11 & 69 & 80 \\
\hline Acetone & 0.5 & 1 & 3.9 & 6.1 \\
\hline n-Heptane & 1 & 3 & 5.5 & 7 \\
\hline Toluene & 0.3 & 3.8 & 7 & 9 \\
\hline Kerosene & 11 & 0.5 & 1 & 1.4 \\
\hline
\end{tabular}

Table 2: Effect of volume and Type of Solvent on Percentage Yield of Oi Produced.

among the main constituent and the matrix of shale. The identification of different minerals through SEM was facilitated by comparing their characteristic morphologies with those shown in the SEM petrology Atlas of Welton [19]. SEM is a qualitative or semi quantitative technique useful for obtaining particle composition and morphology. It was found that is the major phases in oil shale are calcite, clay, and quartz $[20,21]$.

\section{Effect of amount and type of solvent on percentage yield of oil produced}

Table 2 and Figure 8 show the effect of using different kinds of organic solvents and also different volumes of each solvent on the percentage yield of oil produced by solvent extraction. The results revealed that as the volume of solvent increased the percentage yield of oil produced increased. And this trend may be due to that the rate of extraction of bitumen depends on the type of organic solvent used so if the force of attraction between bitumen and solvent is greater than that between the solvent molecules of the dissolution of bitumen, then bitumen can be easily extracted. Results of experiments obviously showed that methanol gives the higher percentage yield of oil than other solvents. These results are in agreement with [21-24]. Figure 8 


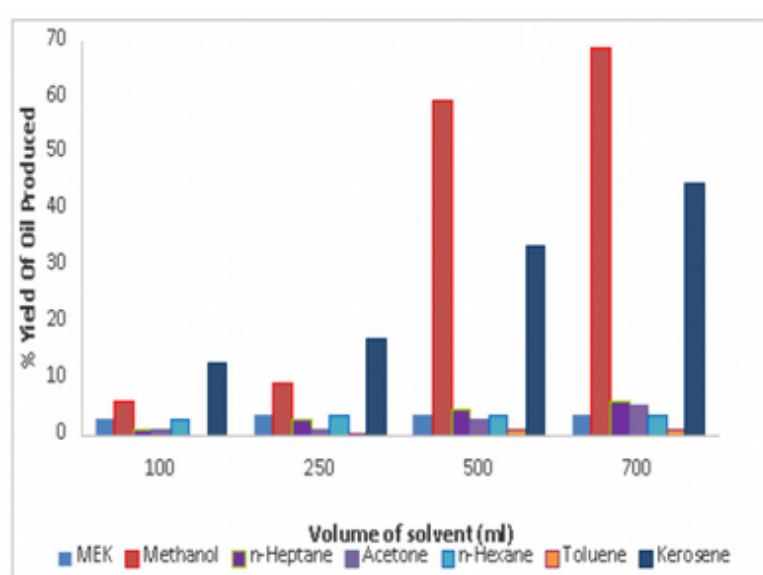

Figure 8: Comparison between different types of solvents on the percentage yield of oil produced.

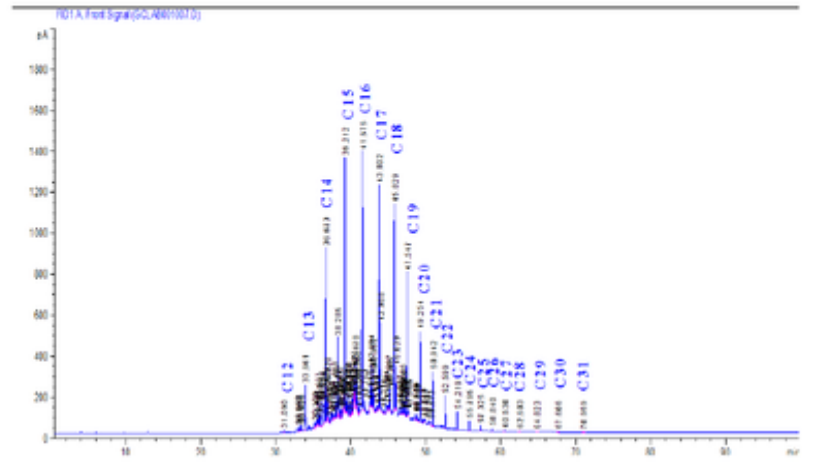

Figure 9: G.C.chart for the oil produced using methanol as a solvent.

shows the comparison between different types of solvent used. From previous table and figure it is seen that the highest percentage yield of shale oil was obtained by using methanol as solvent, followed by kerosene. All other solvents used after that have approximately near percentage yield of oil produced.

\section{Characterization of shale oil by G.C chromatography}

Figure 9 shows the G.C analysis of produced oil sample using Methanol as a solvent. From figure it was shown that the sample contains high hydrocarbon range from C12-C18 in high percentage.

\section{Characterization of shale oil by G.C chromatography}

From Figure 10 it is observed that as the time of extraction increased from $4 \mathrm{hr}$ to $7 \mathrm{hr}$ the percentage yield of oil produced increased. Beyond this time $(7 \mathrm{hr})$ the effect of time is negligible. This time of 7 hours was an indication that the process has received almost completion. Tamimi and Uysal have shown that the effect of extraction time is more significant for larger particle diameter, greater than $2 \mathrm{~mm}$. However in this study all experiments were conducted on particle size $1.5 \mathrm{~mm}$.

\section{Effect of retorting on \% yield of oil produced at $200-300^{\circ} \mathrm{C}$}

From results and comparison of the percentage yield of oil

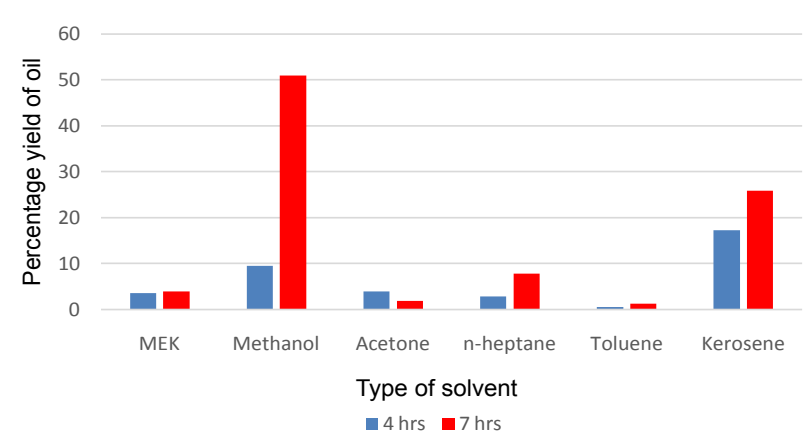

Figure 10: Effect of time on percentage yield of oil produced.

\begin{tabular}{|c|c|c|c|}
\hline \multirow{2}{*}{ Solvent } & Volume of solvent & Yield of oil $(\mathbf{m l})$ & Yield of Oil \\
\cline { 3 - 4 } & & volume & (weight \% ) \\
\hline MEK & 250 & 5.5 & 4.76 \\
\hline Methanol & 250 & 27 & 23.38 \\
\hline Acetone & 250 & 4.9 & 4.24 \\
\hline n- Heptane & 250 & 10.5 & 9.04 \\
\hline Toluene & 250 & 2.5 & 2.16 \\
\hline Kerosene & 250 & 35 & 30.31 \\
\hline
\end{tabular}

Table 3: The percentage yield of oil produced using different solvents

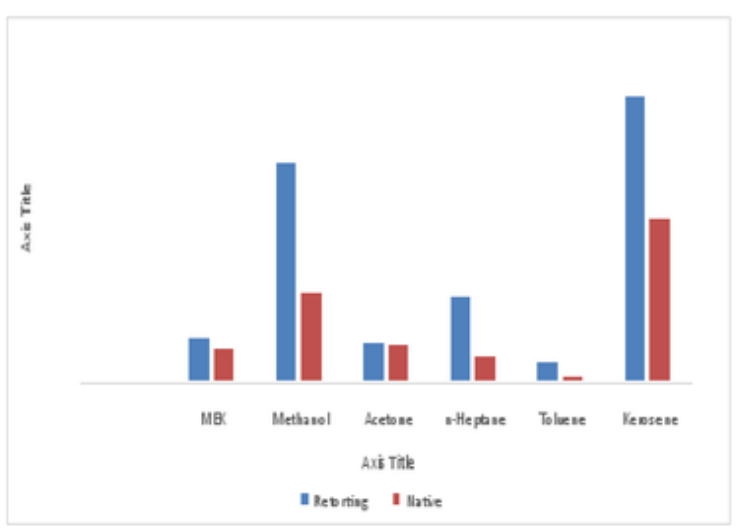

Figure 11: Comparison between retorting shale and native shale on the percentage yield of oil produced.

produced in Table 3 and Figure 11 it was shown that the retorting process increases the yield produced of shale oil.

\section{Conclusions}

- The Elemental analyses of Egyptian Oil shale indicates that it contains lower percentage of S and $\mathrm{N}$ content and Higher H/C ratio than those from Jordanian and Indian oil shale.

- The IR analysis of the shale indicates that contains high percentage of hydrocarbons.

- The Morphology Study of oil Shale (SEM) indicates that the oil shale composed of the major phases present as calcite, clay, and quartz.

- In the present study, the nature of solvent was found to 
have a very significant effect on the yield of recovery and the composition of the oils obtained.

- The oil yield obtained by methanol extraction is significantly higher than those obtained by other solvents.

\section{Recommendations}

- Studying the effect of other organic solvents on the yield of oil produced.

- Applying of other techniques to extract the oil from the shale (e.g. steam).

Measuring the heat content of the oil shale.

\section{References}

1. Andersson A (1985) The Scandinavian Alum Shales. SGU (Geological Survey of Sweden). Ser.Ca, 56.

2. Batista AD, Terabe K (1988) Proceedings International Conference on Oil Shale and Shale Oil. Chemical Industry Press, Beijing, China, 635-642.

3. Bauert H (1994) The Baltic oil shale basin: an overview, Proceedings, Eastern Oil Shale Symposium, University of Kentucky, Institute for Mining and Minerals Research: 411-421.

4. Crisp PT (1987) Australian Oil Shale: A Compendium of Geological and Chemical Data, CSIRO Inst. Energy and Earth Sciences, Division of Fossil Fuels, North Ryde, NSW, Australia, 109.

5. Duncan DC, Swanson VE (1966) Organic rich shale of the United States and world land areas. U.S. Geological Survey, Washington, D.C., USA.

6. Dyni JR (1989) Comparison of hydro retorting, Fischer assay and Rock Evalanalyses of some world oil shales, Eastern Oil Shale Symposium. University of Kentucky Institute for Mining and Minerals Research, 270-286.

7. Hutton AC (1987) Petrographic classification of oil shales. International Journal of Coal Geology 8: 203-231.

8. Stanfield KE, Frost IC (1949) Method of assaying oil shale by a modified Fischer retort. U.S. Bureau of Mines Report of Investigations.

9. Said R (1962) The geology of Egypt. Elsevier, Amsterdam.

10. Kumar R, Bansal V, Badhe RM, Madhira IS, Sugumaran V, et al. (2013) Characterization of Indian origin oil shale using advanced analytical Techniques. Journal of Fuel 113: 610-616.
11. Jaber JO, Sladek TA, Mernitz S, Tarawneh TM (2008) Future policies and strategies for oil shale development in Jordan. JJMIE 2: 31-44.

12. Niu M, Wang S, Han X, Jiang X (2013) Yield and characteristics of shale oil from the retorting of oil shale and fine oil-shale ash mixtures. Journal of Applied Energy 111: 234-239.

13. Wang S, Xiumin J, Han X, Tong J (2012) Investigation of Chinese oil shale resources comprehensive utilization Performance. Journal of Energy 42: 224 232.

14. Bruan V, Halim M, Ziyad M, Largeau M, Ambles A (2001) Characterization of the Moroccan Timahdit (X-layer) oil shale kerogen using pyrolysis and thermally assisted hydrolysis and methylation. J Anal AppIPyrol 61: 165-179.

15. Dogan OM, Uysal BZ (2002) Pyrolysis of three Turkish oil shales and analysis of shale oils using FT-IR and NMR spectroscopy. Oil Shale 19: 399-410.

16. Aboulkas A, Makayssi T, Bilali L, El harfi K, Nadifiyine M, et al. (2012) Copyrolysisof oil shale and High density polyethylene: Structural characterization of the oil. Fuel Processing Technology 96: 203-208.

17. El harfi K, Mokhlisse A, Ben chanâa M (2000) Yields and composition of oil obtained by isothermal pyrolysis of the Moroccan (Tarfaya) oil shales with steam or nitrogen ascarrier gas. J Analytical and Applied Pyrolysis 56: 207-218.

18. Lepage $F$ (1976) Catalyse de Contact. Conception, reparation et mise en oeuvre des catalyseurs industriels, Technip, Paris, France.

19. Welton JE (1984) Chevron Oil Field Research Company, SEM petrology atlas. Tulsa, Okla: American Association of Petroleum Geologists.

20. Al-Otoom AY, Shawabkeh RA, Al-Harahsheh AM, Shawaqfeh AT (2005) The chemistry of minerals obtained from the combustion of Jordanian oil shale. $J$ Energy 30: 611-619.

21. Torrente MC Galan MA (2011) Extraction of kerogen from oil shale (Puertollano, Spain) with supercritical toluene and methanol mixtures. Industrial and Engineering Chemistry Research 50: 1730-1738.

22. Abourriche A, Adil A, Oumam O, Hannache H, Pailler R, et al. (2008) New pitches with very significant maturation degree obtained by super critical extraction of Moroccan oil shale. Journal of Supercritical Fluids 47: 195-199.

23. Abourriche A, Oumam O, Hannache H, Pailler R, Naslain R, et al. (2005) Récupération à l'autoclave de la matièreorganique de schistesbitumineux Marocainspar le phénol en conditions sub-critiques. Annales de Chimie 30: $1-17$.

24. Koel M, Ljovin S, Hollis K, Rubin J (2001) Using neoteric solvents in oil shale studies. Pure and Applied Chemistry 73: 153-159. 